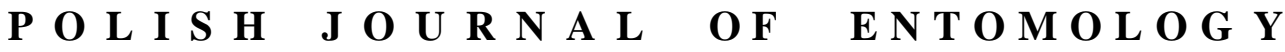

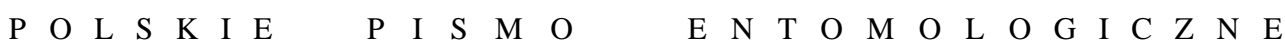

VOL. 85: 389-398

Lublin

31 December 2016

DOI: $10.1515 /$ pjen-2016-0023

\section{Phytodietus elongator AUBERT, 1963 (Hymenoptera, Ichneumonidae, Tryphoninae), a new species to Italy, and a key to the Italian species of the genus Phytodietus GravenHORST, 1829}

\author{
AgAta Kostro-AmbroziaK $^{1 *}$, FilipPo Di GiovanNi ${ }^{2,3}$ \\ ${ }^{1}$ Department of Invertebrate Zoology, Institute of Biology, University of Bialystok, \\ Ciołkowskiego 1J, 15-245 Białystok, Poland \\ ${ }^{2}$ Università di Roma „Sapienza”, Dipartimento di Biologia e Biotecnologie „Charles \\ Darwin”, Sede di Entomologia - Piazzale Valerio Massimo 6, 00185, Roma, Italy \\ ${ }^{3}$ Centro Nazionale Biodiversità Forestale - Bosco della Fontana, Corpo Forestale dello Stato, \\ via Carlo Ederle 16/a, 37100, Verona, Italy
}

\begin{abstract}
Phytodietus elongator has been recorded from Italy for the first time. The hitherto identified subspecies (geographical forms) of this species, P. elongator elongator and P. elongator decoratus, are considered to be merely extreme examples of the variability of this taxon. A checklist and a key to the Italian species of the genus Phytodietus are provided.
\end{abstract}

KEY WORDS: Ichneumonidae, Tryphoninae, Phytodietus, parasitoid, Italy, checklist, key.

\section{INTRODUCTION}

The ichneumonid genus Phytodietus GrAVEnHORST, 1829 is placed in the subfamily Tryphoninae, tribe Phytodietini, and consists of species that are koinobiont ectoparasitoids of semi-concealed larvae of several families of Microlepidoptera (LOAN 1981; KASPARYAN \& SHAW 2008).

The genus is recorded on all the continents except Antarctica and currently includes 122 described species (BENNETT 2015; KASPARYAN \& KHALAIM 2013; Kostro-AMBROZIAK

*Corresponding author: ambro@uwb.edu.pl 
2011a, 2011b, 2012a; KOSTRO-AMBROZIAK \& BROAD 2016). Four subgenera of this genus have been recognized so far (TOWNES 1969; BENNETT 2015), but a recent phylogenetic study has shown that there are only three monophyletic taxa: the widespread Phytodietus GrAVENHORST, 1829, Weisia SCHMIEDEKNECHT, 1907, and Euctenopus ASHMEAD, 1900, endemic to New Zealand; Neuchorus UCHIDA, 1931 has been synonymized with Phytodietus (Kostro-AMBroZIAK 2012b).

To date, 23 species of Phytodietus have been recorded from Europe (GYÖRFI 1944; KASPARYAN \& SHAW 2008; KASPARYAN \& TOLKANITZ 1999; KOLAROV 2003; KOSTROAMBroZiaK 2007a, 2007b; Kostro-AMBroZiaK \& SAWONIEWICZ 2007; ROMAN 1938), six of which are known from Italy (SCARAMOZZINO 1995). Fauna Europaea (ZwAKHALS 2013) gives P. alpinator AUBERT, 1969 from Italy, but as there is no literature record of this species from that country, it has been omitted from the present study.

Here, $P$. elongator is recorded as new to Italy, and a checklist and a key to the Italian species of the genus Phytodietus are provided.

\section{MATERIALS AND METHODS}

One female of $P$. elongator was collected with a Malaise trap (Omnes Artes s. a. s.) in Bosco delle Lame, a lowland oak-hornbeam plantation in the eastern Po Plain (Veneto, Italy). The area is a 23 ha artificial forest surrounded by intensively farmed land and rivers. Like many other artificial forests in the eastern Po Plain, Bosco delle Lame was established about 20 years ago as part of a larger action to restore lowland forest communities on former arable lands and swamps. This material is part of a larger project to investigate the community composition of ichneumonids in fragmented landscapes in natural and artificial oak-hornbeam formations in Italy (see DI GIOVANNI et al. 2015a, 2015b).

Specimens examined in the present study are preserved in the following institutions: BMNH - The Natural History Museum, London, United Kingdom; LEEBI - The Laboratory of Ecology and Evolutionary Biology of Insects, University of Bialystok, Poland; NMS - The National Museums of Scotland, Edinburgh, United Kingdom; ZISP - Zoological Institute, Russian Academy of Sciences, St. Petersburg, Russia; ZMLS - Musée de Zoologie, Place Riponne, Lausanne, Switzerland.

The morphological terminology follows GAULD et al. (1997). The photographs were taken using an opto-digital microscope DSX110 (LEEBI) and the map was made using CorelDrawX5 software. 


\section{RESULTS}

Phytodietus elongator AUBERT, 1963

\section{Material examined}

[I - VENETO - VE - Concordia Sagittaria - fraz. Sindacale, Bosco delle Lame 4541'49.02' 'N 12॰52'9.48' 'E, 21.VII-03.VIII.2013 - impianto Malaise trap 202.], [Phytodietus elongator Aubert, 1963, 9 , det. A. Kostro-AMBrozIAK] - ( 9 , LEEBI).

The female examined was compared with the type material and other specimens: [TYPE], [PHYTODIETUS + , ELONGATOR AUB], [J.F. AUBERT, 9.9.1962, BdR, ISTRES] - (中, ZMLS). [Амурская обл., с. Новороссийка, 31.V.1996, Касрарян], [Рaratypus Phytodietus decorosus] - (†, ZISP). [Hy. Parasites of Salebria formosa, Wilmington, Kent, 22 July 1934, W. RaILt Smith], Phytodietus sp. J.F. Perkins det. III. 1936], [rufipes Holmgr det. Perkins], [Phytodietus elongator AUB. det. G. BrOAD 2008, confirmed D. KASPARYAN] - (1q, BMNH). [ENGLAND WK, Wilmington, 22.vii.1934, W. RAIT. SMITH], [Phytodietus rufipes], [ex Pempelia (Salebrosa) formosa], [Phytodietus elongator Aub. det. G. BROAD 2008, confirmed D. KASPARYAN] - (2犬̂, BMNH). [England: 1 q, Norfolk, Morston Salt Marsh (V.C. 28), 13.08.1980 (M.R. SHAW) MRSH], [Det. KASPARYAN 002] - (1ㅇ, NMS).

\section{Comments}

According to KASPARYAN \& TOLKANITZ (1999) P. elongator is represented by two geographical forms treated as subspecies: P. elongator elongator AUBERT, 1963, recorded from Europe, and P. elongator decoratus TOLKANITZ, 1976, found in the eastern Palaearctic (Amur Oblast, Chita Oblast, Krasnodar Kray, Primor'ye Kray). The latter form is known only from females. It can be separated from the nominal subspecies by the tricoloured (orange-yellow-black) hind coxae and blackish hind first trochanters. The hind coxae and trochanters of the female of $P$. elongator elongator are uniformly orange, whereas the colour pattern of the hind coxae and trochanters of the male is the same as in the female from the eastern Palaearctic (KASPARYAN \& TOLKANITZ 1999). On the basis of these and other characters (e.g. yellow marks on the face), the female from Italy belongs to $P$. elongator decoratus. I have also seen a female from Norfolk in the United Kingdom (NMS) which has orange hind coxae with blackish marks at the base and almost entirely black hind first trochanters, as well as a female from Wilmington (UK) (BMNH) with orange hind coxae, but nearly black or blackish hind trochanters. This shows that the two forms of $P$. elongator are not geographically separated and that there are specimens with an intermediate colour pattern. Thus, we consider the subspecies of $P$. elongator to be merely extreme examples of the variability continuum in this species. 


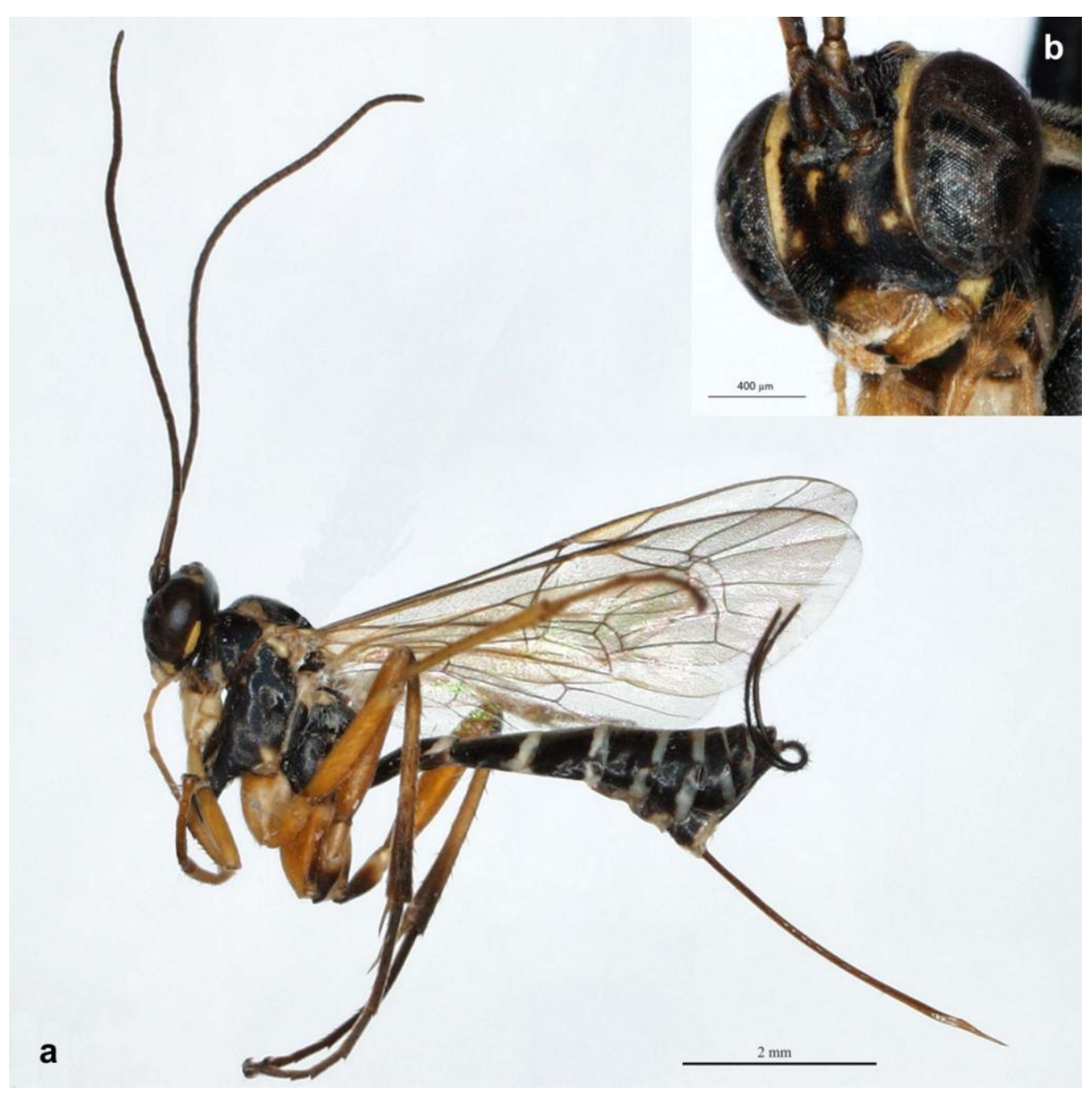

Fig. 1. Habitus (a) and front-lateral view of the head (b) of the female of Phytodietus elongator AUBERT, 1963.

Description. Female from Italy (Figs 1a-b). Body length $7.6 \mathrm{~mm}$.

Head (Fig. 1b). Face 0.70 times as long as wide, subpolished, with very weak leatherlike structure, median area covered with not broad but visible punctures. Clypeus with transverse convexity: basally distinctly convex, apically inclined; its apical margin with weak notch centrally. Upper tooth of mandible longer than lower tooth. Malar space 0.39 times as long as basal width of mandible. Occipital carina complete and joining hypostomal 
carina before base of mandible. Temple behind eye almost linearly narrowed. Antenna with 38 flagellomeres; flagellomeres 1 to 4 unspecialized, not broader than distal one.

Mesosoma. In general polished to subpolished, with short but relatively dense setae. Pronotum smooth, without wrinkles; epomia absent. Mesoscutum 1.24 times as long as wide. Notauli moderately strongly impressed, present anteriorly and extending back to level of tegulae. Mesopleuron subpolished, with shallow but visible punctures and without wrinkles; speculum polished, without punctures and setae. Epicnemial carina distinct, present ventrally and dorsally. Metapleuron covered with fine leather-like sculpture, without wrinkles. Submetapleural carina complete, expanded anteriorly into a lobe (the main part of this lobe is formed by the metapleuron). Propodeum subpolished, smooth, without transverse wrinkles, crests or longitudinal grooves.

Wings. Fore wing length $6.0 \mathrm{~mm}$. Marginal cell 0.26 times as long as wide; areolet present; distance between $2 r s-m$ and $2 m-c u 1.34$ times length of $2 r s-m$; $M$ distinct; $c u-a$ inclivous, postfurcal to $R s \& M$. Hind wing length $4.4 \mathrm{~mm}$. All hind wing veins complete; first abscissa of $\mathrm{Cu} 1$ distinctly longer than $\mathrm{cu}-a$ and joining $\mathrm{cu}-\mathrm{a}$ at a gentle angle.

Legs. Hind femur 5.1 times as long as wide. Hind tibia with rather strong bristles. Lateral spur of hind tibia 0.65 times as long as first metatarsus. Hind fifth tarsomere 0.79 times as long as third.

Metasoma. Tergites polished, with short, moderately dense pubescence, without distinct punctures. First metasomal tergite 2.21 times as long as posteriorly wide, with distinct constriction between base and spiracle. Median basal pit of first tergite rather shallow; median dorsal carinae present but short and superficial. Dorsolateral edge of first tergite moderately angled from base to spiracle, from spiracle to apex not distinctly rounded or angled. Second tergite 1.21 times as long as anteriorly wide and 0.88 times as long as posteriorly wide. Ovipositor sheath about 1.2 times as long as hind tibia.

Colouration (Figs 1a-b). Head black with following parts yellow: mandible (except for brown teeth); apical part of clypeus; maxillary and labial palps; marks on malar space; five small spots on face; broad inner orbital stripe on face, frons and vertex, extending along eye; long stripe on temple, along eye. Antenna dark brown. Mesosoma in general black with following parts yellow: pronotal collar; small round marks on pronotum (above fore coxa) and on mesopleuron (above mid coxa and below tegula); tegula; triangular anterolateral and irregular medial marks on mesoscutum; most of scutellum; postscutellum; mark on metapleuron (above hind coxa); $\Omega$ - shaped broad band on apical part of propodeum. Fore and mid legs yellow-pale orange; coxae nearly completely pale yellow. Hind leg: coxa pale orange with pale yellow dorsal marks basally and with very small, irregular dorsal blackish mark; first trochanter basally blackish, apically dark yellow; second trochanter yellow; femur pale orange; tibia blackish, a little paler medially; tarsus 
dark brown. Wings transparent, pale yellowish-brownish; veins brown. First and following metasomal tergites black with apical and lateral yellow bands. Ovipositor sheath black.

\section{Distribution}

P. elongator has already been recorded in Bulgaria, Croatia, France, Romania, Russia, Ukraine and the United Kingdom (YU et al. 2012) (Fig. 2). This is the first record of this species from Italy.

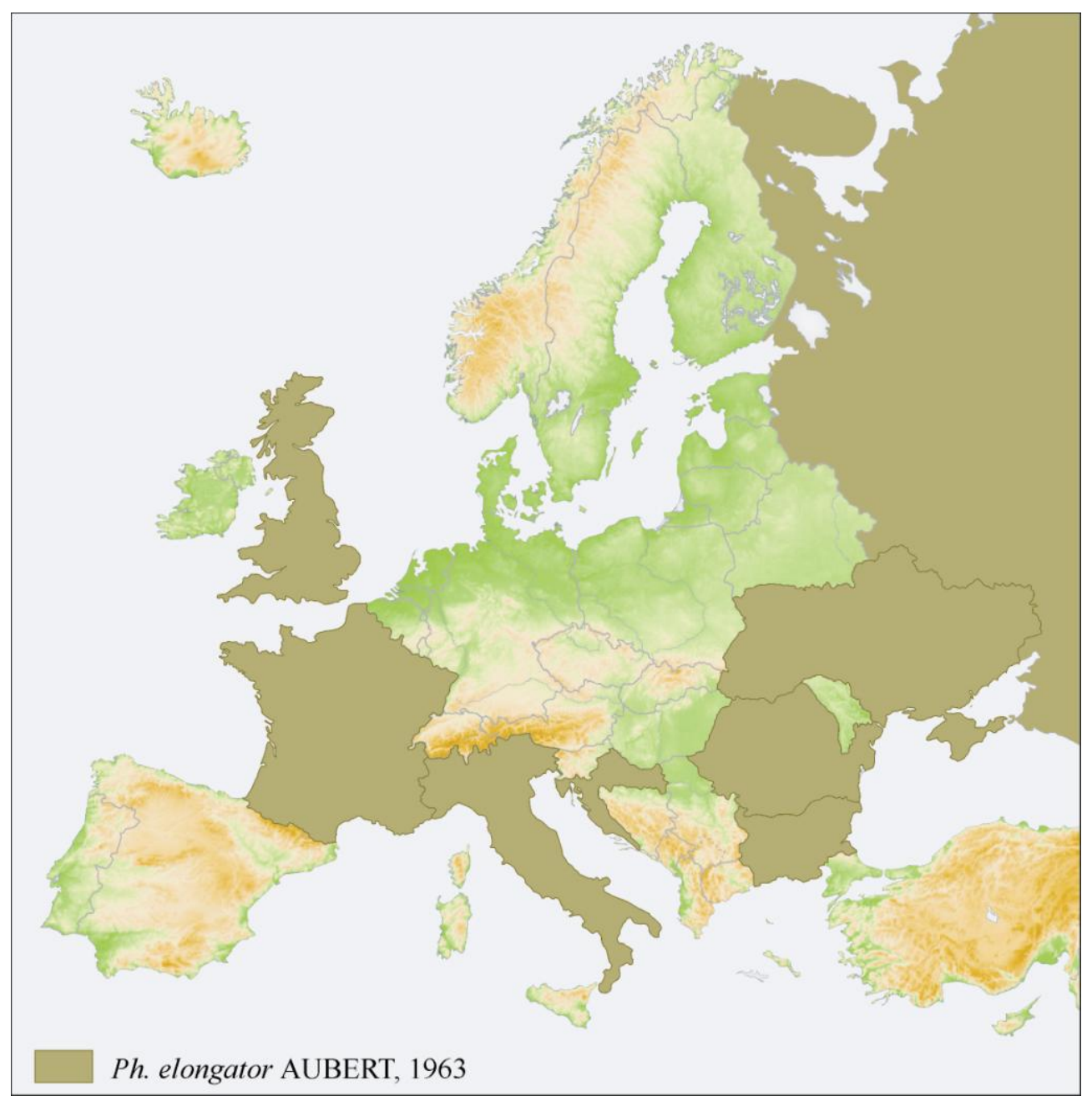

Fig. 2. Distribution of Phytodietus elongator AUBERT, 1963. 


\section{Biological notes}

The data suggest that $P$. elongator has more than one generation per year. It has been recorded in April and May in Bulgaria (KOLAROV 2003) and Ukraine (KASPARYAN \& Tolkanitz 1999), in May, June, July, August and September in Russia (KASPARYAN 1993; KASPARYAN \& TOLKANITZ 1999; TOLKANITZ 1976), in July and August in the United Kingdom (KASPARYAN \& SHAW 2008) and Italy, and in July and September in France (AUBERT 1963, 1969). In Italy, P. elongator was collected in a 20 year-old lowland oak-hornbeam plantation in eastern Po Plain of Italy. The forest tree community consists of Acer campestre L., Carpinus betulus L., Fraxinus sp., Quercus robur L., Salix alba L. and Ulmus minor MILL.

P. elongator is known to be a parasitoid of the moth Rhodophaea formosa (HAWORTH, 1811) (Pyralidae) (KASPARYAN \& SHAW 2008).

\section{A checklist of the genus Phytodietus GRAVENHORST, 1829 recorded from Italy}

The species' names are used according to YU et al. (2012).

- P. arcuatorius (THUNBERG, 1822)

- P. astutus GRAVENHORST, 1829 (= obscurus DESVIGNES, 1856)

- P. elongator AUBERT, 1963

- P. gelitorius (THUNBERG, 1822) (= coryphaeus GRAVENHORST, 1829)

- P. griseanae KERRICH, 1962

- P. obscurus (RATZEBURG, 1852) (= rufipes HolMGREN, 1860)

- P. polyzonias (FÖRSTER, 1771)

\section{Key to the Italian species of the genus Phytodietus GravenHORST, 1829}

1. First metasomal tergite slender (about 2.0 and more times as long as posteriorly wide), with distinct constriction between base and spiracle; epomia distinct. . . . . . . 2 .

- First metasomal tergite gradually narrowing from apex to base (about 1.3-1.5 times as long as posteriorly wide), without constriction between base and spiracle; epomia

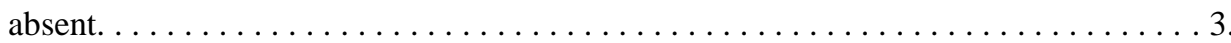

2. Fore and mid coxae black, hind coxa orange; malar space 0.77-0.88 times as long as basal width of mandible. . . . . . . . . . . . . . obscurus (RATZEBURG, 1852).

- All coxae orange or yellow (hind coxa orange, sometimes with yellow spot at base and/or with black spot at apex); malar space 0.38-0.57 times as long as basal width of mandible. ....................... elongator AUBERT, 1963.

3. Scutellum entirely black, or at least base of scutellum black; all coxae black. . . . . 4.

- Scutellum yellow with black spots or black with yellow spots; not all coxae black (fore and mid coxae black and hind coxa orange with black spot or all coxae orange, or some of them yellow, sometimes with black spots) $\ldots \ldots \ldots \ldots \ldots \ldots \ldots \ldots \ldots \ldots \ldots \ldots \ldots \ldots \ldots$. 
4. Mesopleuron with deep punctures and visible wrinkles; clypeus of female all black or only at base, remainder dark brown or, in male, entirely yellow; apical margin of clypeus with distinct notch centrally............. P. astutus GRAVENHORST, 1829.

- Mesopleuron with more or less distinct punctures but without wrinkles; clypeus yellow (female and male); apical margin of clypeus without notch centrally; pterostigma often pale yellow.............................. . griseanae KerRICH, 1962.

5. Temple behind eye narrowed; face of female black, often with yellow spot medially and with yellow inner orbital stripe, extending along eye; clypeus yellow (female and male). ................................... polyzonias (FöRSTER, 1771).

- Temple behind eye distinctly rounded; face of female entirely black; clypeus blackish or brown (female) or yellow (male) $\ldots \ldots \ldots \ldots \ldots \ldots \ldots \ldots \ldots \ldots \ldots \ldots \ldots \ldots \ldots \ldots \ldots$.

6. Clypeus not strongly convex, its apical margin with narrow but deep notch centrally; hind tibia black....................... arcuatorius (THUNBERG, 1822).

- Clypeus basally distinctly convex, apically inclined; apical margin of clypeus with broad but shallow notch centrally; hind tibia orange, often darkened or black at apex. . P. gelitorius (THUNBERG, 1822).

\section{ACKNOWLEDGEMENTS}

We are very grateful to Gavin BROAD (BMNH), Anne FreItAG (ZMLS), Dmitriy R. KASPARYAN (ZISP) and Mark SHAW (NMS) for the loan of the materials examined in this study. We would also like to thank ALEXEY RESHCHIKOV for his helpful editorial suggestions.

\section{REFERENCES}

AubERT J.F. 1963. Les Ichneumonides du rivage méditerranéen français (Hymenoptera) $6^{\mathrm{e}}$ série: Pimplinae, Banchinae, Tryphoninae, Scolobatinae, Orthocentrinae, Diplazontinae, Metopiinae, Microleptinae de I'Hérault et des Bouches-du-Rhône. Bulletin de la Société Entomologique de France 68: 91-100.

AUBERT J.F. 1969. Les Ichneumonides du rivage méditerranéen français (10e série: Alpes-Maritimes) (Hym.). Bulletin de la Société Entomologique de France 74: 37-47.

BenNetT A.M.R. 2015. Memoirs of the American Entomological Institute, Volume 86. Revision of the World Genera of Tryphoninae (Hymenoptera: Ichneumonidae). American Entomological Institute, Gainesville, FL. 
Di Giovanni F., Cerretti P., Mason F., Minari E., Marini L. 2015a. Vertical stratification of ichneumonid wasp communities: the effects of forest structure and life-history traits. Insect Science 22(5): 688-699.

Di Giovanni F., Reshchikov A., Riedel M., Diller E., Schwarz M. 2015b. New records of Ichneumonidae (Hymenoptera) for the Italian fauna. Biodiversity Data Journal 3: e5057.

Gauld I., Wahl D., Bradshaw K., Hanson P., Ward S. 1997. Memoirs of the American Entomological Institute, Volume 57. The Ichneumonidae of Costa Rica, 2. Introduction and keys to species of the smaller subfamilies, Anomaloninae, Ctenopelmatinae, Diplazontinae, Lycorininae, Phrudinae, Tryphoninae (excluding Netelia) and Xoridinae, with an appendix on the Rhyssinae. American Entomological Institute, Gainesville, FL.

GYÖRFI J. 1944. Vier neue Ichneumoniden-Arten aus Ungarn. Fragmenta Faunistica Hungarica 7(2-3): 42-45.

KaSParyan D.R. 1993. Review of Palearctic species of wasps of the genus Phytodietus Grav. (Hymenoptera, Ichneumonidae). Entomologicheskoye Obozreniye 72(4): 869-890.

Kasparyan D.R., Khalaim A.I. 2013. A new species of the genus Phytodietus Gravenhorst, 1829 (Hymenoptera: Ichneumonidae: Tryphoninae) from Mexico. Proceedings of the Zoological Institute RAS 317(1): 110-114.

KASPARYAn D.R., SHAw M.R. 2008. British and European Phytodietus GRAVEnHORST (Hymenoptera: Ichneumonidae, Tryphoninae) in the National Museums of Scotland, with a key to European species of the subgenus Neuchorus UCHIDA and descriptions of three new species. Entomologist's Gazette 59: 184-198.

KASPARYAN D.R., TolkanitZ V.I. 1999. Fauna of Russia and neighbouring countries. Insecta Hymenoptera, New Series 143, 3(3). Ichneumonidae. Subfamily Tryphoninae: tribes Sphinctini, Phytodietini, Oedemopsini, Tryphonini (addendum), Idiogrammatini. Subfamilies Eucerotinae, Adelognathinae (addendum), Townesioninae. Nauka, Saint Peterburg

Kolarov J. 2003. New Phytodietini (Hymenoptera, Ichneumonidae, Tryphoninae) species from Bulgaria. Acta Zoologica Bulgarica 55(3): 43-48.

Kostro-Ambroziak A. 2007a. Phytodietus alpinator Aubert, 1969 (Hymenoptera, Ichneumonidae) new species to the fauna of Poland. Supplementation of the checklist of Polish Phytodietus GRAVENHORST, 1829. Polish Journal of Entomology 76(2): 115-118.

Kostro-Ambroziak A. 2007b. A new species of the genus Phytodietus Gravenhorst, 1829 (Hymenoptera: Ichneumonidae) from Poland. Annales Zoologici 57(4): 823-826.

Kostro-Ambroziak A. 2011a. Phytodietus (Weisia) pearlus sp. nov. from South Africa (Hymenoptera: Ichneumonidae). Annales Zoologici 64(4): 803-805.

Kostro-Ambroziak A. 2011b. A new species of Phytodietus Gravenhorst, 1829 (Hymenoptera: Ichneumonidae: Tryphoninae) from north Africa. Entomological News 122(2): 149-153.

Kostro-Ambroziak A. 2012a. Taxonomic study of the genus Phytodietus Gravenhorst, 1829 (Hymenoptera: Ichneumonidae) from Australia, with description of a new species. Deutsche Entomologische Zeitschrift 59(1): 139-145.

Kostro-Ambroziak A. 2012b. Revision and phylogeny of the genus Phytodietus Gravenhorst, 1829 (Hymenoptera: Ichneumonidae). PhD Thesis, University of Białystok, Faculty of Biology and Chemistry, Białystok. (in Polish) 
Kostro-Ambroziak A., Broad G. 2016. Genus Phytodietus Gravenhorst, 1829 new to South America, with description of a new species (Hymenoptera, Ichneumonidae, Tryphoninae). Annales Zoologici 66(1): 53-56.

Kostro-Ambroziak A., Sawoniewicz J. 2007. Phytodietus (Phytodietus) antennator Kasparyan, 1993 (Hymenoptera, Ichneumonidae) a new species to the European fauna. Polish Journal of Entomology 76(1): 57-60.

LOAN C.C. 1981. North American species of Phytodietus and Neuchorus (Hymenoptera: Ichneumonidae, Tryphoninae). Naturaliste Canadien 108: 331-470.

Roman A. 1938. Die Arthropodenfauna von Madeira nach den Ergebnissen der Reise von Prof. Dr. O. LundBLAD Juli-August 1935. Arkiv för Zoologi 30(1): 1-26.

SCARAmozzino P.L. 1995. Checklist delle specie della fauna italiana 94. Hymenoptera Ichneumonidae. Calderini, Bologna.

TolkanitZ V.I. 1976. New eastern Palearctic species of the genus Phytodietus GRAV. (Hymenoptera, Ichneumonidae). Vestnik Zoologii 5(1): 76-78.

Townes H. 1969. Memoirs of the American Entomological Institute, Volume 11. The genera of Ichneumonidae, part 1. American Entomological Institute, Gainesville, FL.

Yu D.S., van Achterberg C., Horstmann K. 2012. Ichneumonoidea 2011. Taxapad 2012. Flash drive version, Vancouver, Canada.

ZwAKHALS K. 2013. Fauna Europaea: Ichneumonidae. [in:] C. vAN ACHTERBERG (ed.). Fauna Europaea: Hymenoptera: Symphyta - Ichneumonoidea. Fauna Europaea version 2.6. Internet: http://www.faunaeur.org.

Received: 17 February 2016

Accepted: 22 June 2016 